Most of these instruments are operated on behalf of the electrical industry. Research is being carried out on the imaging properties of electron lenses, and the production of high voltages using high-frequency oscillators. Investigations are being pursued into the scattering properties of electrons and the interaction of electrons and the photographic plate.

An exhibition of photomicrographs was held illustrating the topics dealt with at the conference, and interesting large-scale demonstrations of optical diffraction effects were given by Prof. Kossel.

T. MUlvey

\section{PRIMITIVE MEDICINE AT THE WELLCOME HISTORICAL MUSEUM}

$\mathrm{O}$

$\mathrm{N}$ July 18 the new exhibition at the Wellcome Historical Medical Museum, 28 Portman Square, London, W.1, which bears the title "The Medicine of the Aboriginal Peoples in the British Commonwealth", was officially opened, and on that occasion Lord Webb-Johnson delivered an address. In his introductory remarks the director of the Museum, Dr. Ashworth Underwood, explained that the scope of the exhibition has been restricted to the primitive races in the Commonwealth in order to enable the subject to be covered in the limited space available; this arrangement nevertheless allows of a crosssection of the world to be illustrated.

The exhibition is divided into a number of sections which lead from general primitive conceptions, through ideas regarding the nature of disease, to its treatment by non-rational and by rational methods. The sequence then follows the detailed methods used in treatment, and the practices which are employed for the protection of the individual, both against disease and danger in general, and also against specific ailments.

In the section dealing with general knowledge various fine carvings, such as a genealogical stave, should be mentioned. In the section dealing with the cause of disease, attention should be directed to the fine series of sago-pith effigies from Borneo, to the various memorial heads, the finely carved soulcatchers, and to the unique exhibit illustrating the cult of the god of smallpox in the Yoruba mythology. The practice of the medicine man himself is well illustrated, and the very complete outfits actually used by certain individual medicine-men will be of the greatest interest. This section contains a number of fine carvings, especially the spirit-masks and the front-pieces of ceremonial head-dresses.

In the section dealing with treatment, attention should be directed to the outfit actually used by the personal medicine man to Cetewayo, which contains a number of horns used for cupping purposes. The various instruments and operations shown in the section on surgery illustrate the ingenuity of primitive peoples in making very simple instruments serve a specific purpose. The practice of artificial deformation is illustrated by some most interesting specimens, including a rare preserved head showing the practice of elaborate facial tattooing which, among the Maori, was reserved for chiefs and other important persons.

The ritual background on which primitive medicine rests is shown by a number of most interesting carvings, some of which are used as masks in the ceremonies of various secret societies. These exhibits cannot be easily described; but attention should be directed to the very fine carved elephant's tusk from Benin which epitomizes so much of the background of African ritual and legend.

All the exhibits in this exhibition are selected from the collections in the Museum. The exhibition deals with subjects which are little known, and the detailed catalogue includes the fruits of extensive research. The catalogue is published by the Oxford University Press* on behalf of the Museum.

* "Catalogue of an Exhibition illustrating the Medicine of the Aboriginal Peoples in the British Commonwealth." Pp. xviii $+58+$ 6 plates. (Published by the Wellcome Historical Medical Museum by Geoffrey Cumberlege, Oxford University Press.) 3s. 6d.

\section{SOUTH-WESTERN NATURALISTS' UNION}

\section{CONFERENCE AT PLYMOUTH}

7 HE South-Western Naturalists' Union held its annual Whitsuntide conference during May $30-$ June 2 at Plymouth, at the invitation of the Plymouth and District Field Club and the Plymouth Institution. Some eighty members attended.

On May 30, the Mayor of Plymouth (Alderman $\mathbf{H}$. Wright) received the delegates and members at the City Art Gallery. Afterwards Mr. H. G. Hussell showed a series of films illustrating the animal and plant life of the neighbourhood.

Most of Saturday, May 31, was taken up by a river excursion up the Tamar as far as Calstock. Mr. G. M. Spooner pointed out features of interest along the route ; in the afternoon Cotehele House, formerly owned by the Earl of Edgecombe and now in the possession of the National Trust, was visited.

In the evening, Mr. Mervyn G. Palmer gave his presidential address ; his subject was "Lundy". In his comprehensive survey of the island, he dealt with the geology, topography and history of Lundy and with its animal and plant life, paying particular attention to the birds.

A coach tour across the southern part of Dartmoor occupied most of June 1 , and the hut circles at Grimspound and the stone avenue and menhirs at Merrivale were visited. Mr. Spooner again acted as leader.

The annual general meeting, following a meeting of the Council of the Association, was held on June 2. In his report, the honorary secretary, Dr. Stanley Smith, stated that at the present time the Union embraces twenty-two societies, one institution and one private member. A letter from the honorary secretary of the Ilfracombe Field Club inviting the South-Western Naturalists' Union to hold its next conference at Ilfracombe was then read, and the invitation accepted. Mr. Mervyn Palmer agreed to continue in office as president for another year, and the other officers were all re-elected : Hon. Secretary, Dr. Stanley Smith (University, Bristol, 8); Hon. Assistant Secretary, Miss Elizabeth Fleure; Hon. Treasurer, Mr. H. W. Turner; and Hon. Auditor, Dr. F. S. Wallis, Mr. G. M. Spooner, Mr. G. Tipper and Mr. O. G. Watkins were added to the Council.

On behalf of everyone present, Mr. Palmer thanked the Plymouth societies for their hospitality and all individual members of the Plymouth and District Field Club and Plymouth Institution who had contributed to the success of the conference. He particularly mentioned Mr. O. G. Watkins, who had 
carried out the duties of local secretary, and Mr. Spooner, who acted as leader in the field.

Members had the choice of one of three excursions on the afternoon of June $2:$ a visit to the Aquarium and Laboratory of the Marine Biological Association; Ruckland Abbey; and Plympton Castle.

\section{SOVIET FAMILY LEGISLATION}

CONSIDERING the concept of the family in $\checkmark$ Soviet life Dr. R. A. J. Schlesinger suggests that the U.S.S.R. does not just represent an attempt at the application of socialist theories in a modern industrial society. In considering any matter in the U.S.S.R. it should be realized that it is not a country but a continent; at the time of the Bolshevik revolution Russia comprised a greater variety of civilizations than it does at present, after a systematic process of industrialization (Health Educ. J., 10, No. 2 ; April 1952).

In some areas until quite recently millions of peasant homes in Russia were man-dominated in the most brutal sense of the term, and women's condition deteriorated, at least in the poor peasant's home when the economic differentiation in the village increased its dependence on the richer neighbour. Of the Islamic regions some- especially the Volga Tartarswere fairly advanced; but most of them (especially Central Asia) belonged to the most backward provinces of the Islamic world. There were large areas over which a primitive tribal organization was still in operation. As late as 1936 the Government struggle against blood-feud was just in its concluding stage. Large sections of the penal codes of the Republics concerned dealt with paying bride-price, abducting women, polygamy, marriage of minors and similar "offences originating from tribal custom", some of which (for example, marriage of minors) came under heavy penal sanctions only if they were caused by local custom which the legislator wished to repress in the interest of the emancipation of women.

Confronted with the initiation of a revolution in human relations against the prejudices of primitive custom, the Soviet state has firmly kept to the Marxist concept that undesirable phenomena in family life should, and can, be overcome by the removal of their economic causes. In 1935 Stalin hailed the Labour Day as the great emancipator of peasant women because it granted them an income independent of that of their menfolk. To-day the Soviet Government is attempting to construct a modern industrial society in which its policies aim at stabilizing family relationships in such a society.

Before this were possible, however, certain 'housecleaning' had to be concluded. In the 'house-cleaning' programme the first enactments of the revolutionary Government did not exceed measures current in modern legislation elsewhere. They were revolutionary only in comparison with 'Tsarist Russian legislation and consisted of such measures as the transfer of marriage and divorce from the Church to the registrar's office, admission of divorce on the joint petition of both parties, or by court decision on the petition of only one party, the decision being left to the judge's discretion.

Much confusion about the real social situation has been created and is still being created by exaggerated emphasis on some literary pronouncements. Even in statements by authors who must be regarded as characteristic of the Soviet outlook, concepts of an eventual withering away of the family played a predominant part. The withering process, however, always referred to the family as an economic unit of consumption and as the main place of education, and not as a normally permanent union of man and wife. To some extent this may have been due to the impact of the more Utopian elements of Marxist ideology, to some extent to exaggerated estimates of the potentialities of some measures which are clearly necessary in order to enable women to take their share in production, such as creches, pre-school education and public canteens.

This view has now completely changed and, in all Soviet publications since 1936, the family is described with great fervour as "the primary unit of our Soviet society". The Ministry of Education publishes a special monthly, Family and School, to promote collaboration between home and school and the activities of parents' committees. Great emphasis is laid upon the responsibilities, not only of parents towards their children, but also of the younger members of the family towards the aged ones. The reasons for this change are political as well as economic.

After having passed its revolutionary period-. which, a posteriori, is explained by the consideration - that it was necessary in order to break up some millions of unfree relationships and to establish the principle of equality of the sexes-Soviet legislation, as enacted in the period 1936-45, has come to conclusions very similar to those current in other advanced industrial countries. Most of the differences may be explained by the absence of traditional prejudice; the Soviet State can leave the decision upon whether a divorce should be granted or not to the judge's common sense, without binding him by enumerating grounds for divorce, the presence of which gives a claim to, and the absence of which excludes, granting of a divorce. It can also encourage marriage without paying tribute to the concept that being an unmarried mother is morally wrong.

In essence, however, the conclusions arrived at are the same: marriage is the normal way to motherhood; the family home is the ordinary, though not the only, place to rear the new generation; men and women have equal rights within the family as well as in professional life. The real problems of the Soviet approach to the family arise less from the consummation of the permanent results of the feminist movement than from the potential contradiction between the recognition of the family home as one centre in the education of the future citizen and the demand for the access of women, not only in theory, but also in practice, to all professions for which they are physically fitted.

\section{INHIBITION OF CESTRUS BY CULTIVATED GROMWELL}

By DR. B. P. WIESNER and PROF. JOHN YUDKIN Department of Physiology, King's College of Househo'd and Social Science (University of London)

$\mathrm{N}$ one settlement of the Shoshone Indians, infusions of the roots of Lithospermum ruderale, Dougl. taken orally, were believed to have contraceptive properties. ${ }^{1}$ Prompted by this, Cranston ${ }^{2}$ administered fluid extracts of the herb to mice in their food. She observed inhibition of cestrus and fertility during treatment, without any evidence of general toxicity. 